\title{
EVOLUTION OF THE U.S. ASSISTANCE PROGRAM AND THE SOVIET “ECONOMIC OFFENSIVE” FACTOR (1950s)
}

\author{
Sergey Yu. Shenin \\ Saratov State University, Saratov, Russian Federation
}

\begin{abstract}
Introduction. This article is devoted to studying the influence of the Soviet "economic offensive" factor in the 1950s on the formation of the New World Economic Order by the American by the American ruling elite in general and the use of such an important tool as foreign assistance in particular in the framework of this process. The reconstruction of this process makes it possible to clarify the specifics of the foreign policy decision-making mechanism in the United States, to identify the ideological approaches of main political interest groups to the goals and methods of building a new world order. Methods and materials. The study uses a group analysis approach as well as American executive and legislative documents, press material, speeches by key politicians, etc., to identify the reasons for the differences among representatives of the three leading interest groups in interpreting the nature of the Soviet "economic offensive" in the Third World countries. Analysis. These differences were primarily due to the possibility of using the factor of the Soviet "aggression" for conducting domestic propaganda campaigns as part of the interest groups struggle for control over the foreign assistance program. Thus, the representatives of the atlantists group claimed that the main threat from the Communist world remained in the military sphere; the globalist-oriented progressives insisted that the Soviet "economic offensive" was a critical danger to U.S. interests, while conservatives declared that the "myths" about the Soviet-communist threats to the United States in the Third World were invalid. Results. In the second half of the 1950s the group of progressives used the factor of the Soviet "economic offensive" more effectively in the framework of their campaigns (there were four of them), which allowed them to take control over the foreign assistance program and begin to reorient the American strategic course from the prevailing ideology of "mutual security" towards the global developmentalism.
\end{abstract}

Key words: economic assistance, mutual security, development assistance, globalization, Soviet "economic offensive", Third World, atlantists, progressives, conservatives.

Citation. Shenin S.Yu. Evolution of the U.S. Assistance Program and the Soviet "Economic Offensive" Factor (1950s). Vestnik Volgogradskogo gosudarstvennogo universiteta. Seriya 4. Istoriya. Regionovedenie. Mezhdunarodnye otnosheniya [Science Journal of Volgograd State University. History. Area Studies. International Relations], 2021, vol. 26, no. 4, pp. 148-159. (in Russian). DOI: https://doi.org/10.15688/jvolsu4.2021.4.13

УДК 327(73)

ББК 66.4

Дата поступления статьи: 24.02.2020 Дата принятия статьи: 05.06.2020

\section{ЭВОЛЮЦИЯ АМЕРИКАНСКОЙ ПРОГРАММЫ ПОМОЩИ И ФАКТОР СОВЕТСКОГО «ЭКОНОМИЧЕСКОГО НАСТУПЛЕНИЯ» (1950-е ГГ.)}

\section{Сергей Юрьевич Шенин}

Саратовский национальный исследовательский государственный университет им. Н.Г. Чернышевского, г. Саратов, Российская Федерация

Аннотация. Данная статья посвящена изучению влияния фактора советского «экономического наступления» в 1950-е гг. на процесс формирования американской правящей элитой нового мирового экономического порядка в целом и применения в рамках этого процесса такого важнейшего инструмента, как внешняя помощь, в частности. Реконструкция этого процесса дает возможность уточнить особенности работы механизма принятия внешнеполитических решений в США, выявить идеологические подходы отдельных политических групп интересов к целям и методам строительства нового миропорядка. На основе документов аме- 
риканской исполнительной и законодательной властей, материалов прессы, выступлений ключевых политиков и т. д. в исследовании анализируются причины разногласий представителей трех ведущих групп интересов по вопросу характера «экономического наступления» СССР в странах третьего мира. В первую очередь эти разногласия были связаны с трактовкой фактора советской «агрессии» для проведения внутренних пропагандистских кампаний в рамках борьбы групп интересов за контроль над программой внешней помощи. Так, представители группировки «атлантистов» утверждали, что главная угроза со стороны коммунистического мира по-прежнему лежала в военной сфере, прогрессисты глобалистской ориентации настаивали на критической опасности советского «экономического наступления» для американских интересов, а консерваторы заявляли о несостоятельности «мифов» о советско-коммунистических угрозах для США в третьем мире. Прогрессистская группировка во второй половине 1950-х гг. использовала рассматриваемый фактор в рамках своих кампаний (их было четыре) более эффективно, что позволило ей взять программу помощи под свой контроль и начать поворот американского стратегического курса с господствовавшей идеологии «взаимной безопасности» в сторону глобального девелопментализма.

Ключевые слова: экономическая помощь, взаимная безопасность, помощь развитию, глобализация, советское «экономическое наступление», третий мир, атлантисты, прогрессисты, консерваторы.

Цитирование. Шенин С. Ю. Эволюция американской программы помощи и фактор советского «экономического наступления» (1950-е гг.) // Вестник Волгоградского государственного университета. Серия 4, История. Регионоведение. Международные отношения. - 2021. - Т. 26, № 4. - С. 148-159. - DOI: https://doi.org/10.15688/jvolsu4.2021.4.13

Введение. Как известно, сразу после окончания Второй мировой войны внутри правящей элиты США сложился консенсус по вопросу о том, что новый мировой экономический порядок (далее - НМЭП) должен базироваться на принципах «специализации, стандартизации и упрощения», лежащих в основе американской системы предпринимательства. Лидеры американского правящего класса были также едины в том, что послевоенный мир должен функционировать на основе принципов «открытых дверей», прозрачных границ и универсальных международных правил, то есть того, что потом составит смысл феномена глобализации.

Однако этот консенсус носил самый общий характер, в то время как по вопросу путей реализации этой стратегии, а также применяемых инструментов (торговой, кредитной и налоговой политики, субсидий, военной силы, дипломатии и т. д.) у различных групп интересов имелись серьезные расхождения. Особенно острая борьба развернулась за контроль над внешнеэкономической помощью. Критическая важность этого инструмента объяснялась тем, что практически все страны мира, пострадавшие в результате войны, остро нуждались в помощи извне и были готовы ее принять. Было очевидно, что те группировки, которые получат возможность использовать этот инструмент, смогут направить процесс строительства НМЭП в желаемое русло своих интересов.
Тем не менее на предыдущем этапе своей истории Соединенные Штаты этим инструментом не пользовались, поэтому опыта обращения с ним у них практически не было. Особенно остро эта проблема проявила себя в вопросе финансирования программ помощи, поскольку сама идея была (и, кстати, остается) весьма непопулярной у американского электората, которому трудно подняться до понимания важности использования больших денег в вопросах внешней политики.

Соответственно, первым послевоенным администрациям было исключительно сложно получить в конгрессе деньги на финансирование программ помощи, а деньги нужны были очень большие. Поэтому заинтересованным группировкам приходилось устраивать общенациональные агитационно-пропагандистские кампании, чтобы убедить общественное мнение и конгрессменов в важности финансирования данного направления. Для проведения таких кампаний группы использовали различные факторы, но самым эффективным среди них оказалось «экономическое наступление» СССР в зоне национально-освободительного движения. В данном контексте представляется важным проанализировать пути использования ведущими группировками этого фактора (в мировой историографии советское «экономическое наступление» достаточно хорошо изучено $[12 ; 16 ; 26])$, а также выяснить степень его влияния на эволюцию 


\section{МЕЖДУНАРОДНЫЕ ОТНОШЕНИЯ В ПРОШЛОМ И НАСТОЯЩЕМ}

политики внешней помощи США в рассматриваемый период.

Методы и материалы. Решение данной научной задачи требует в первую очередь использования исторического и системного методов. Это связано с тем, что формирование хронологической последовательности событий позволяет лучше понять закономерности эволюции стратегического курса США в 1950-е гг., а системный подход к оценке деятельности ведущих групп интересов дает более полное представление о трансформации инструмента помощи и его применении в контексте факторов «советских угроз» и «коммунистической экспансии» в странах третьего мира. В работе использовался круг источников, среди которых наиболее важными являются документы американской исполнительной и законодательной властей, материалы прессы, выступления ключевых политиков и т. д.

Анализ. В 1950-е гг. внутри американского истеблишмента существовали три основные группировки, которые имели свою стратегию построения НМЭП и рассматривали этот процесс через призму собственных экономических интересов, - военно-бюрократическая, прогрессистско-кейнсианская и консервативно-рыночная.

Так, военно-бюрократическая группировка сформировалась в период Второй мировой войны. Ее лидеры (Д. Ачесон, У. Клэйтон, А. Даллес и т. д.) базировали свою глобальную стратегию на представлении о том, что универсальный и многосторонний мировой порядок может быть построен первоначально только на части планеты, которая должна называться «свободный мир» и охватывать Северо-Атлантический регион (Северную Америку и Западную Европу). «Атлантисты» считали, что для такого строительства необходимо использовать конфликтные, хотя и «негорячие» методы, что и было реализовано в рамках феномена холодной войны. В этом контексте вся внешнеэкономическая помощь должна была направляться исключительно на цели и задачи военно-политического «сдерживания» СССР.

Группировка прогрессистов (идеология которых сильно отличалась от взглядов современной одноименной группы) в целом состо- яла из крупных руководителей гражданского промышленного сектора. Стратегической целью лидеров этой группы (П. Хоффмана, Ф. Рида, Н. Рокфеллера и т. д.) было создание таких глобальных универсальных экономических и финансовых условий, в рамках которых можно было формировать новые рынки для сбыта продукции из США, а американские бизнесмены имели бы возможность работать по привычным и удобным для них правилам и нормам. Глобалисты полагали, что осуществлять данные реформы следует американскому правительству, а бизнес-сообщество должно иметь возможность направлять эту активность. Так называемая «помощь развитию» должна была стать основным инструментом указанных реформ.

Ядро консервативной группировки, возглавлявшейся Дж. Хэмфри, Г. Гувером-мл., Р. Хьюзом и т. д., в основном состояла из представителей обрабатывающих, энергетических и сырьевых отраслей. Консерваторы строили свою глобальную стратегию на традиционных методах чисто рыночной (без вмешательства правительства) экспансии американского капитала. В их схеме правительство США и его внешняя помощь должны были играть вспомогательную роль, обеспечивая корпорациям благоприятные политические и экономические условия в развитых и особенно слаборазвитых регионах мира [4, p. 20-32].

Как известно, во второй половине 1940-х гт. активное использование фактора «советской агрессии» позволило демократической администрации Г. Трумэна постепенно, шаг за шагом сформировать и включить в работу механизм внешнеэкономической помощи. При этом элитарные группировки в жесткой конкурентной борьбе по очереди перехватывали рычаги управления этим механизмом.

Так, в 1946 г. кампания в американской прессе против «агрессивных подрывных» действий Москвы в отношении таких суверенных стран, как Греция и Турция, позволила администрации активно продвигать «доктрину сдерживания» и убедить конгресс в необходимости предоставить первую масштабную помощь «жертвам» «советской экспансии» $[1$, p. 208-209].

В 1948 г. использование жупела распространения «коммунистической угрозы» на За- 
падную Европу и «советизации» Москвой стран Центральной и Восточной Европы дало возможность уже группировке прогрессистов перехватить инициативу и получить у законодателей 17 млрд долл. на такой смелый шаг, как «план Маршалла». Главной идеей данной программы становилось инициирование процесса европейского экономического развития, который в перспективе подразумевал подключение к нему нейтральных и даже некоторых «советизированных» стран.

Правда, уже следующая программа помощи, «Пункт-4», провозглашенная Г. Трумэном в 1949 г. и нацеленная на поддержку слаборазвитых стран, не получила сочувствия и требуемых денег в конгрессе, поскольку прямой коммунистической угрозы для региона не наблюдалось, а «советская агрессия» в Европе была уже купирована «планом Маршалла». Тем не менее в этот период (1948-1950 гг.) прогрессисты уверенно контролировали все инструменты американской помощи, необходимые для формирования глобального рынка $[2 ; 3]$.

Однако начало Корейской войны позволило сторонникам военной бюрократии перейти в контрнаступление. Эта война очень убедительно трактовалась «атлантистами» как переход лагеря коммунизма (СССР, КНР и КНДР) от «холодной» к «горячей» фазе глобального конфликта. Эти новые страхи дали возможность данной группе полностью взять под контроль все виды помощи, для чего конгрессом была принята Программа взаимной безопасности (Mutual Security Program MSP), для реализации которой администрацией Трумэна было создано специализированное Агентство взаимной безопасности (Mutual Security Agency - MSA).

Идеология «взаимной безопасности» предполагала жесткий «черно-белый» подход к предоставлению помощи по формуле «или с нами, или против нас». Соответственно, помощь могли получить только те страны, которые открыто присоединились к лагерю «сдерживания», а нейтральные государства (большинство слаборазвитых стран относили себя именно к этой категории) претендовать на нее уже не могли [17].

В целом Корейская война стала очень мощным инструментом ослабления прогрес- систского влияния на процесс формирования НМЭП и укрепления идеологии «атлантизма». Прогрессисты, утратив рычаги построения глобального миропорядка, включая помощь, находились в панике. Это заставило их приступить к поискам политического лидера, который мог бы выиграть выборы в 1952 г. и остановить этот губительный для них тренд.

Таким лидером стал генерал Д. Эйзенхауэр, являвшийся по своим взглядам противником холодной войны и сторонником глобализации. Соответственно, предполагалось, что он должен был закончить Корейскую войну и вражду с коммунистическим миром, создать условия для продвижения глобализационной модели НМЭП, для чего требовалось перехватить и перестроить главные внешнеполитические инструменты [15].

В первую очередь это касалось помощи, которую нужно было переориентировать с Западной Европы, ставшей уже к 1953 г. в результате действия «плана Маршалла» конкурентом для американского бизнеса, на интеграцию в НМЭП потенциальных и реальных партнеров как в освободившихся странах, так и в соцлагере. Правда, поскольку внешняя помощь оставалась очень непопулярной у электората, особенно после гигантских выплат по «плану Маршалла», Эйзенхауэр в рамках предвыборной кампании на волне обычного в таких случаях популизма даже обещал ее ликвидировать в случае прихода в Белый дом.

Став президентом, он последовательно приступил к решению своей главной задачи постепенно переориентировать внешнеполитическую стратегию США с «атлантизма» на глобализм. При этом ему удалось быстро закончить Корейскую войну и начать процесс налаживания отношений с СССР, который результировался в «духе Женевы». Тем не менее Советский Союз и мировой коммунизм не перестали быть угрозой для западного мира, об этом в США невозможно было даже начинать разговор. Поэтому MSP и ее философию нельзя было отменить - можно было только аккуратно начать интегрировать в программу глобалистские идеи и инструменты, которые могли бы постепенно начать ее разъедать.

Главным таким инструментом считалась внешняя помощь. Эйзенхауэр сразу и без ко- 


\section{МЕЖДУНАРОДНЫЕ ОТНОШЕНИЯ В ПРОШЛОМ И НАСТОЯЩЕМ}

лебаний передал все рычаги управления ею группировке прогрессистов (получившим в администрации прозвище «младотурки»), которые предложили президенту жесткий план перестройки механизма помощи под новые цели. В результате вместо MSA была создана Администрация внешних операций (Foreign Operation Administration - FOA) во главе с политическим тяжеловесом и радикальным прогрессистом Г. Стассеном.

Новая структура представлялась более централизованной и координируемой, с ее помощью «младотурки» планировали начать стратегическое смещение целого ряда акцентов в рамках MSP - с краткосрочных задач безопасности на долгосрочные цели экономического развития, с военных программ на гражданские, с Европы на Азию, с грантов на кредиты, с точечных проектов технической помощи на масштабное экономическое планирование [11, p. 486].

Создав новый мощный механизм помощи, Г. Стассен планировал с начала 1954 г. приступить к реализации своих планов. Однако, совершенно предсказуемо, он наткнулся на нежелание американского общественного мнения и конгресса выделять деньги на новые планы, так как в условиях смягчения общего внешнеполитического курса уже нельзя было широко использовать фактор «советской агрессии», шантажировать общество внешними угрозами. Стратегия глобализации, снижения военно-политической напряженности, сближения с СССР (чего, собственно, хотели сами прогрессисты) входила в противоречие с необходимостью получить одобрение планов расширения помощи со стороны электората, ибо исчез «чрезвычайный контекст», внешние факторы, которые могли бы стимулировать избирателя поддержать новый курс.

Конечно, Стассен попытался обратиться к «советской угрозе». Однако, учитывая то, что говорить о «военной агрессии» было уже нежелательно (это противоречило стратегическому курсу президента), он стал утверждать, что новое руководство СССР выбрало путь «экономической агрессии», который включал в себя помощь Афганистану, кредиты Индии и т. д. Однако это был слабый аргумент - в такое наступление Москвы никто в США не верил. Оппоненты из консерватив- ной группировки утверждали, что это миф, а если даже такие факты имели место, то русские занимаются лишь имитацией американской помощи, а значит, конкурировать с США не могут: у них для этого просто нет денег [3, c. 59-61].

В такой отчаянной ситуации на выручку «младотуркам» пришел Вьетминь, который одержал решающую победу над французами в мае 1954 года. Стассен немедленно попытался объяснить, что за поражением Франции во Вьетнаме также стояла подрывная активность Москвы. В прогрессистской прессе немедленно началась кампания, в которой победа вьетнамских коммунистов подавалась как составная часть глобального коммунистического наступления [21].

«Легкий испуг» публики дал президенту предлог официально поддержать усилия Стассена по созданию постоянного ядра «помощи развитию» внутри MSP. Хотя администрация официально не объясняла, как она собирается использовать фонды «помощи развитию» в Азии, пропрогрессистские СМИ (к которым можно отнести такие республиканские и демократические издания, как «The New York Times», «The Washington Post and Times Herald», «Chicago Daily News» и т. д.) немедленно начали еще одну пропагандистскую кампанию, призывая использовать методику «плана Маршалла» для остановки «коммунистической агрессии» в Юго-Восточной Азии (далее - ЮВА).

Основная идея 〈плана Маршалла для Азии» (далее - ПМА) заключалась в том, чтобы восстановить экономику региона с Японией в качестве «мотора» и использовать местные рынки и источники сырья для экономик стран Западной Европы. Несмотря на ожесточенное сопротивление оппозиции, ПМА был принят, однако деньги на него были выделены конгрессом очень небольшие - всего 200 млн долл.

Стассен был разочарован, но надеялся, что это только первый шаг и потом можно будет финансирование нарастить. Однако в конечном итоге он не получил ПМА даже в урезанном виде, поскольку в мае 1955 г. на конференции в Симле (Индия) азиатские страны - участницы отвергли многосторонний региональный принцип ради сохранения двухсторонней американской помощи [7]. 
На этой печальной ноте попытка переформатирования механизма помощи под глобалистские цели закончилась, прогрессисты потерпели поражение. Несмотря на симпатии к ним, Эйзенхауэр был вынужден признать это поражение, уволить Стассена, ликвидировать FOA, а вместо последней в середине 1955 г. создать более скромную структуру - Администрацию международного сотрудничества (International Cooperation Administration ICA) - и отдать ее под контроль прямых конкурентов - группировки консерваторов. Директором ICA был назначен ставленник корпораций, крупный бизнесмен и миллионер из Огайо Дж. Холистер.

Со стратегической точки зрения консерваторы были нацелены на борьбу с уже появляющимся дефицитом бюджета, выступали за повсеместную экономию, урезание госрасходов, что в первую очередь касалось внешней помощи. Последнюю необходимо было сокращать, но, одновременно, адаптировать под корпоративные интересы: она должна была помогать крупным компаниям выходить на рынки других стран и получать там хорошие заказы. Исходя из этой стратегии, Холистер радикально сократил сумму запроса к конгрессу на финансирование помощи (с 4 до 2,5 млрд долл.) и стал откровенно использовать ее для продвижение интересов крупных корпораций $[29$, p. 3$]$.

Прогрессисты были обескуражены и попытались осенью 1955 г. охарактеризовать такую политику как «преступную» перед лицом советского «экономического наступления». Однако консерваторы смело заявили, что «экономическое наступление» Москвы это блеф, при этом избиратели и конгресс в целом их поддержали [4, p. 108]. Таким образом, тренд на полное сворачивание инструмента помощи был обозначен. Эйзенхауэр, как хорошо известно, всегда вставал на сторону большинства, и в данном вопросе он был готов уступить: в конце концов, в 1952 г., будучи кандидатом в президенты, генерал обещал ликвидировать помощь, и теперь, перед выборами 1956 г., он мог отчитаться за свое обещание, если вдруг консерваторы доведут дело до конца.

Однако, к счастью для «младотурок»глобалистов, во второй половине ноября два советских лидера, Н. Хрущев и Н. Булганин, начали свое месячное турне по странам Южной Азии - Афганистану, Индии и Бирме. В ходе этой поездки они щедро предлагали техническую помощь и займы на развитие, открыто призывая США конкурировать с СССР именно в этой сфере [28].

Это был момент уникальной возможности для «младотурок» в администрации начать фронтальную контратаку против консерваторов. Прогрессисты немедленно инициировали кампанию в прессе, которая была нацелена на то, чтобы представить ситуацию в Южной Азии как «более чем опасную», «почти как кризисную» [9]. Утверждалось, что «Советский Союз привнес нечто новое в отношения Запада и Востока, а именно экономическое и политическое наступление в так называемой неприсоединившейся трети мира, особенно на Ближнем Востоке и Южной Азии» [23]. Соответственно, «от идеи сокращения программ внешней помощи в 1956 г. можно спокойно отказаться» [23].

Эта кампания очень быстро качнула баланс сил внутри администрации в пользу прогрессистов, позволив президенту открыто занять сторону радикалов. Реакция Эйзенхауэра была молниеносной - в течение нескольких дней запрос на финансирование помощи на следующий, 1956 г. вырос до почти фантастических 5 млрд долл.

Таким образом, используя визит Хрущева, «младотурки» из администрации смогли спасти программу помощи и влить в нее новую энергию. Однако это был пока не тот качественный разворот MSP от военно-политического «сдерживания» к «помощи развитию», о котором мечтали прогрессисты.

Коренной перелом в данном вопросе произошел после президентских выборов в ноябре 1956 г., которые уверенно выиграл Эйзенхауэр. Холистер был быстро уволен, а «машину помощи» президент сразу же без колебаний опять вручил прогрессистам ICA возглавил преданный сторонник президента Дж. Смит [27, р. 381-382]. Кроме того, в сенате демократы сформировали мощную пропрогрессистскую группу Фулбрайта - Кеннеди, которая активно поддерживала «младотурок» в республиканской администрации. 


\section{МЕЖДУНАРОДНЫЕ ОТНОШЕНИЯ В ПРОШЛОМ И НАСТОЯЩЕМ}

Если в конце 1955 г. прогрессистам удалось спасти помощь как инструмент глобализации, то в начале 1957 г., получив значительное внутриполитическое преимущество над оппонентами из консервативной и военно-бюрократической группировок, имея своего человека во главе агентства помощи и поддержку в конгрессе, а самое главное, президента в качестве единомышленника (хотя и очень осторожного), «младотурки» приступили к радикальному качественному развороту внешнеэкономической стратегии, в первую очередь в сфере помощи. Его главная цель заключалась в необходимости дискредитировать философию «взаимной безопасности», расчистить идеологическое поле для проникновения идей «глобального девелопментализма».

Несмотря на внушительное политическое преимущество, было ясно, что для публичного обоснования такого радикального шага нельзя было обойтись без обращения к «внешней угрозе». Началась мощнейшая и уникальная по своей организованности пропагандистская кампания в СМИ, которой дирижировал один из лидеров радикальных глобалистов С.Д. Джексон. При этом все участники дискуссии демонстрировали редкое единство взглядов и аргументации.

Главная идея кампании заключалась в том, что советская помощь перестала быть «одним из аспектов холодной войны», она превратилась в ее «сердцевину», главный инструмент, а стратегическим направлением «коммунистического наступления» стал регион освободившихся стран. Москва выбрала такую стратегию потому, что использование военно-политического инструментария, особенно в Европе, себя исчерпало.

Объясняя причины такого разворота СССР, прогрессистские издания указывали, что во второй половине 1950-х гг., после Суэцкого кризиса, Бандунгской конференции, лавинообразного нарастания процесса деколонизации и создания десятков новых государств, которые должны были выбрать, по какому пути им развиваться, США не могли более руководствоваться старой стратегий, сформулированной в 1951 г. в рамках Закона о взаимной безопасности. Данный закон требовал от тех стран, которые претендуют на получение помощи, блоковой солидарности и участия в военно-политическом «сдерживании» СССР. Однако почти все освободившиеся страны выбрали «неприсоединение» или нейтралитет, рассматривая при этом включение в западные военные блоки только как замену европейского империализма американским [8].

Пользуясь такой неповоротливостью Вашингтона, утверждали пропагандисты С.Д. Джексона, Москва начала идеологическое наступление, главным инструментом которого стала экономическая помощь, выглядевшая намного привлекательнее американской. Так, русские не «прикрепляли» к своим пакетам помощи какие-либо условия (например, проведение реформ), как это делал Вашингтон, а позволяли освободившимся странам самим планировать проекты развития. Кроме того, Москва не предоставляла безвозмездную помощь (гранты), а предпочитала мягкие займы, которые также выглядели более привлекательно для новых государств. Наконец, СССР был согласен на возврат кредитов в форме сырьевой продукции (у Египта хлопок, у Бирмы - рис, у Индии - чай и т. д.), а не твердой валютой [26].

Выбранный Москвой подход представлял собой самый легкий путь навязать коммунистическую идеологию, в первую очередь ее экономический аспект. Если советские займы и специалисты будут приниматься более благосклонно слаборазвитыми странами, утверждали прогрессисты, то тоталитарная часть их экономик - государственный сектор - будет развиваться более активно по мере расширения советской сферы влияния. В то же время США начнут терять экономические возможности (рынки и источники сырья), что может стать для них смертельным ударом. «Если эти страны будут вынуждены полагаться на помощь Советского Союза и начнут постепенно играть роль его сателлитов, то мы столкнемся со всеми опасностями, которые будет нести с собой сжатие свободного мира» [14, p. 213].

Но самая главная опасность для США заключалась в том, что СССР, используя свою помощь, мог перенаправить «националистический импульс» в деструктивное антизападное русло [5, p. 6-7]. Исходя из этого, новая долгосрочная программа американской помощи 
должна была фокусироваться не столько на борьбе с советским «экономическим наступлением» как таковым (что составляло смысл концепции «взаимной безопасности»), сколько на развороте этих националистических настроений в конструктивное русло экономического прогресса (концепция «помощи развитию»).

В условиях усиливавшегося национализма помощь являлась единственным инструментом, позволявшим США влиять на ситуацию в третьем мире. Однако слаборазвитые страны были готовы принять помощь, только если она была направлена не на борьбу с американскими врагами, а соответствовала их целям, главной среди которых являлся рост уровня жизни [14; 18$]$.

Аналитики прогрессистской ориентации подчеркивали: «...вы не можете купить друзей или лояльность. Но вы можете показать людям свою заинтересованность в их усилиях улучшить собственную жизнь... Вы можете помочь людям помочь себе и тем самым построить сильные нации, способные защитить свою собственную свободу. Общая заинтересованность в свободе делает страны хорошими союзниками. Нет сомнений, что это самый крепкий бастион защиты от коммунистической агрессии» [20].

Обосновывая долгосрочный характер новой стратегии помощи, прогрессисты указывали, что «единственным честным ответом будет то, что она должна продолжаться всю нашу жизнь и, возможно, жизнь наших детей» [24, p. 2459]. «США должны продолжить посылать миллиарды за рубеж до тех пор, пока русские не откажутся от своих планов захватить мир. Поскольку такой итог русской активности крайне маловероятен, то программа помощи США... должна продолжаться очень долго» [19].

Результаты пропагандистской кампании прогрессистов были весьма впечатляющими. Опросы общественного мнения представлялись особенно важными для продвижения нового плана через конгресс. Так, с глубоким удовлетворением подчеркивалось, что в 1957 г. 71 \% опрошенных граждан считал, что экономическая помощь союзникам США была важнее, чем военная поддержка (в 1951 г. таких было только $51 \%$ ). 52 \% оп- рошенных поддерживали экономическую помощь для таких нейтральных стран, как Индия. Самая большая доля опрошенных (49 \%) считала, что долгосрочные программы - «хорошая идея». Таким образом, делался вывод, что в целом общественное мнение поддерживало изменение философии американской программы помощи [13, p. 700; 25, p. 437].

Используя инерцию этой успешной кампании, прогрессисты сумели сделать следующий революционный шаг. Уже в 1957 г. они добились создания внутри MSP новой структуры помощи в виде Фонда займов на развитие (Development Loan Fund - DLF). В рамках фонда можно было выделять долгосрочные кредиты не только странам-союзникам, но и нейтральным государствам без привязки к идеологии «взаимной безопасности».

Однако, добившись создания DLF, прогрессисты столкнулись с нежеланием конгресса выделять для него достаточное финансирование. Кроме того, было ясно, что в течение 1958 г. эта модернизированная структура помощи будет проходить период становления и не сможет приносить реальных результатов. Bce это могло поставить DLF и всю концепцию «помощи развитию» под удар оппозиции. Поэтому, чтобы сохранить фонд и получить финансирование, прогрессисты в 1958 г. начали новую пропагандистскую кампанию, описывающую все ужасы «коммунистического наступления».

Теперь подчеркивалось, что это наступление не ограничивалось ЮВА, а приобрело глобальный характер. Южная Азия, Ближний Восток, Южная Америка - везде в 1958 г. наблюдалось энергичное советское «экономическое проникновение». Так, общая помощь Москвы, переданная 11 ключевым странам Ближнего Востока, составила 1,9 млрд долл., из которых 1,5 млрд долл. были предоставлены в форме экономической помощи, в то время как США предоставили странам региона лишь 900 млн долл. Кроме того, американская программа покрывала более широкий регион, чем советская помощь, которая концентрировалась на таких важнейших в стратегическом отношении странах, как Египет, Цейлон и Йемен [10].

При этом указывалось, что «Советы создали большой и явно высокоэффективный 


\section{МЕЖДУНАРОДНЫЕ ОТНОШЕНИЯ В ПРОШЛОМ И НАСТОЯЩЕМ}

механизм помощи» [27, p. 389]. Советский полевой персонал превышал американский в 11 важнейших странах в соотношении 2570 к 1890 человек. «Советские специалисты явно великолепны - в отношении профессиональной подготовки, аккуратного общения с местным населением, часто языковых возможностей, и они готовы жить и работать в суровых условиях» [27, p. 389].

Группа демократов в сенате также активизировала использование риторики о «советской угрозе». Особенно активен был молодой сенатор Дж. Кеннеди. Он настаивал, что «реальная угроза со стороны советско-китайской коалиции заключается не в том, что она может обогнать нашу страну в промышленном производстве, а в том, что она отчуждает от США наших союзников и друзей в неприсоединившейся части мира» [30]. Сенатор утверждал: «1959 год станет нашим раундом... И если мы будем сейчас действовать в правильном направлении и в правильных рамках, то мы сможем сократить этот постоянно растущий разрыв» [22, р. 157].

Неожиданно прогрессистов поддержал даже Г. Трумэн, который утверждал, что «начиная с 1953 года Советский Союз добился колоссальных успехов в своем экономическом наступлении, в то время как мы торговали военными пактами. <...> Это та сфера, в которой Кремль может доставить свободному миру больше проблем, чем, возможно, он мог бы со всеми своими ракетами и пропагандой в духе холодной войны» [6].

Все эти цифры и факты должны были подтвердить правильность нового курса администрации и необходимость хотя бы подтянуть американские фонды «помощи развитию» к советскому уровню. В целом используемый подход оказался плодотворным: на очередной, 1959 г. конгресс заметно увеличил фонды DLF и несильно возражал против особого акцента на регионы Ближнего Востока, Латинской Америки и Южной Азии. Впервые, начиная с Корейской войны, экономическая помощь в рамках MSP превысила военную [17, p. 135].

Таким образом, к концу 1950-х гг. прогрессисты уверенно перехватили инициативу в отношении формирования внешнеэкономической политики США и принципов использо- вания помощи. Президенту Эйзенхауэру это не очень нравилось, он даже старался их притормаживать (например, с помощью так называемого «доклада Драппера»), пытаясь не допустить разбалансировки интересов внутри MSP.

Однако ситуация в мире во все большей степени доказывала правильность такой стратегической коррекции. Так, в 1960 г., когда Америка готовилась к президентским выборам, на карте мира появилось более десятка новых независимых государств. Они были полны молодой националистической энергии и явно не собирались слишком долго терпеть свое униженное экономическое положение. В США становилось ясно всем, что пытаться перетягивать их на свою сторону через участие в блоках типа «взаимной безопасности» бессмысленно. С другой стороны, было бы чрезвычайно опрометчиво бросать их на произвол судьбы, поскольку «экономическое наступление» коммунистического блока продолжало набирать силу (с 1954 по 1960 г. Москвой и Пекином было предоставлено кредитов на 3,8 млрд долл.) и ничто не могло остановить новые государства от получения советской или китайской помощи, если она им понадобится.

В результате большинство наблюдателей и экспертов в США было уверено, что любая вновь выбранная администрация, демократическая или республиканская, столкнется с необходимостью более решительно продолжить смещение главного акцента своих внешних усилий с военно-политического «сдерживания» на долгосрочную «помощь развитию».

Дж. Кеннеди, выиграв президентские выборы, на волне своей победы предпринял ряд шагов в сторону дальнейшего ослабления MSP, расширения «помощи развитию», продвижения стратегии девелопментализма. В первую очередь ему удалось создать специализированное агентство (Agency for International Development - AID) и получить большие деньги на программу «Союз ради прогресса», которая предполагала глубокое реформирование стран Латинской Америки. Летом 1961 г. в Вене он пытался лично убедить Н.С. Хрущева остановить свое «экономическое наступление», намекая на возмож- 
ность расширить латиноамериканскую программу на весь третий мир. Однако советский лидер не видел смысла уступать: он был уверен в том, что СССР выбрал правильную стратегию, которая скоро довершит «общий кризис капитализма».

Результаты. Таким образом, можно сказать, что на протяжении 1950-х гг. три самые влиятельные группы интересов в правительстве США активно конкурировали между собой за контроль над программой помощи, которая являлась самым эффективным инструментом строительства НМЭП. При этом самым сильным аргументом в этой борьбе явились советская и коммунистическая угрозы. Именно активность Москвы или Пекина в третьем мире становилась ядром пропагандистских кампаний в сражениях за голоса в конгрессе. Таких кампаний в 1950-е гг. было четыре, и все они были инициированы прогрессистами. Так, в 1954 г. они пытались разыграть «вьетнамскую карту» для продвижения «плана Маршалла для Азии»; в конце 1955 г. ими был остановлен «консервативный реванш», направленный на ликвидацию всей программы помощи; в начале 1957 г. им удалось наконец интегрировать в MSP первый инструмент «помощи развитию» - DLF; а в 1958 г. прогрессисты сумели обеспечить полноценное финансирование этого инструмента.

В целом во второй половине 1950-х гг. прогрессистская группировка использовала свои аргументы в ходе пропагандистских кампаний более эффективно, что позволило ей взять программу помощи в рамках MSP под свой контроль и начать переориентацию внешнеэкономической стратегии США с господствовавшей доктрины «взаимной безопасности» в сторону глобалистской концепции «помощи развитию». Указанный тренд достиг своего пика в начальный период президентства Дж. Кеннеди.

\section{СПИСОК ЛИТЕРАТУРЫ}

1. Бартенев, В. И. Американские программы помощи зарубежным странам в области безопасности: прошлое, настоящее, будущее / В. И. Бартенев // Вестник Московского университета. Серия 25, Международные отношения и мировая политика. 2016. - № 4. - C. 204-234.
2. Глазунова, Е. Н. У истоков содействия международному развитию: американская программа технической помощи развивающимся странам / Е. Н. Глазунова // Вестник Московского университета. Серия 25 , Международные отношения и мировая политика. - 2012. - № 2. - С. 126-157.

3. Шенин, С. Ю. Помощь США слаборазвитым странам. Гарри Трумэн и «пункт-4» / С. Ю. Шенин. Саратов : Изд-во СГУ, 2017. -228 p.

4. Шенин, С. Ю. Помощь США слаборазвитым странам. Дуайт Эйзенхауэр и «отбрасывание» коммунизма / С. Ю. Шенин. - Саратов : Изд-во СГУ, 2018. $-272 \mathrm{p}$.

5. Acheson, D. What is Point Four? Address by the Secretary of State, January 25, 1952 / D. Acheson. Washington, D.C. : GPO, 1952. - 12 p. - (Department of State Publication No. 4487).

6. Aid Funds Urgent, Truman Declares // The New York Times. $-1959 .-5$ Apr. - P. 45.

7. Asia As a Region // The New York Times. 1955. - 16 May. - P. 22.

8. Bowles, C. The Challenge of the Next Decade / C. Bowels // The New York Times Magazine. - 1957. 21 Apr. - P. 189, 206-208.

9. Bowles, C. The Crisis That Faces Us Will Not Wait / C. Bowels // The New York Times Magazine. 1955. - 27 Nov. - P. 245, 266-270.

10. Cut in Interest for Aid is Balked // The New York Times. - 1958. - 19 Jan. - P. 59.

11. Eisenhower, D. Report to Congress on the Mutual Security Program/D. Eisenhower // Department of State Bulletin. - 1954. - Vol. 30, № 770. - P. 484-490.

12. Goldman, M. Soviet Foreign Aid/M. Goldman. N. Y.; Washington ; L. : Praeger, 1967. - 265 p.

13. Haviland, H. Foreign Aid and the Political Process: 1957 / H. Haviland // The American Political Science Review. - 1958. - Vol. 52, № 3. - P. 689-724.

14. Hoffman, P. Blueprint for Foreign Aid/P. Hoffman // The New York Times Magazine. - 1957. - 17 Febr. P. 213, 237-239.

15. Hoffman, P. World Investment, not Foreign Aid / P. Hoffman // The New York Times Magazine.1952. - 3 Febr. - P. 185, 204-206.

16. Kaufman, B. The United States Response to the Soviet Economic Offensive of the 1950s / B. Kaufman // Diplomatic History. - 1978. - Vol. 2, № 2. - P. 153-165.

17. Kaufman, B. Trade and Aid: Eisenhower's Foreign Economic Policy, 1953-1961 / B. Kaufman. Baltimore : John Hopkins University Press, 1982.$296 \mathrm{p}$.

18. Lacy, D. Foreign Aid: Is It Still Necessary? / D. Lacy // Harper's Magazine. - 1957. - 16 Febr. P. 71-80.

19. McGaffin, W. Foreign Aid to Stay On /W. McGaffin // Chicago Daily News. - 1957. -6 Mar.P. 17. 
20. More Foreign Aid Urged by Hoffman // Chicago Daily News. - 1957. - 1 May. - P. 22.

21. Reston, J. A Gain for President / J. Reston // The New York Times. - 1954. - 5 Aug. - P. 2.

22. Rostow, W. Eisenhower, Kennedy, and Foreign Aid / W. Rostow. - Austin : University of Texas Press, 1985. - $342 \mathrm{p}$.

23. Schmidt, D. Policy Appraisal Urged on Dulles / D. Schmidt// The New York Times. - 1955. - 29 Nov. P. 1.

24. Speech by Sen. Hubert H. Humphrey, February 12, 1957 // Congressional Record. Proceedings and Debates of the $85^{\text {th }}$ Congress, $1^{\text {st }}$ Session. - Washington, D. C. : GPO, 1957. - Vol. 103, part 2. -P. 1421-2848.

25. Staley, E. The Future of Underdeveloped Countries: Political Implications on Economic Development / E. Staley. - N. Y. : Harper, 1961. - 483 p.

26. Thorp, W. American Policy and the Soviet Economic Offensive / W. Thorp // Foreign Affairs. 1957. - Vol. 35, № 2. - P. 271-282.

27. U.S. Congress. House of Representatives. Mutual Security Act of 1958. Hearings before the Committee on Foreign Affairs on H.R.12181. $85^{\text {th }}$ Congress, $2^{\text {nd }}$ Session. - Washington, D. C. : GPO, 1958. $-992 \mathrm{p}$.

28. U.S. Congress. Senate. Foreign Assistance Activities of the Communist Bloc and Their Implications for the United States. $85^{\text {th }}$ Congress, $1^{\text {st }}$ Session. - Washington, D. C. : GPO, 1957. - 134 p.

29. U.S. International Cooperation Administration. Office of Public Reports. Background for Mutual Security. - Washington, D. C. : GPO, 1955. - 26 p.

30. Wehrwein, A. Kennedy Visions Wide Negro Role / A. Wehrwein // The New York Times. -1959. 13 Apr.-P. 56.

\section{REFERENCES}

1. Bartenev V.I. Amerikanskie programmy pomoshhi zarubezhnym stranam $\mathrm{v}$ oblasti bezopasnosti: proshloe, nastojashhee, budushhee [U.S. Security Assistance Programs: Past, Present, Future]. Vestnik Moskovskogo universiteta. Serija 25, Mezhdunarodnye otnoshenija i mirovaja politika [Moscow University Bulletin of World Politics], 2016, no. 4, pp. 204-234.

2. Glazunova E.N. U istokov sodejstvija mezhdunarodnomu razvitiju: amerikanskaja programma tehnicheskoj pomoshhi razvivajushhimsja stranam [At the Origins of International Development Cooperation: The U.S. Program of Technical Assistance to Underdeveloped Countries]. Vestnik Moskovskogo universiteta. Serija 25, Mezhdunarodnye otnoshenija i mirovaja politika [Moscow University Bulletin of World Politics], 2012, no. 2, pp. 126-157.
3. Shenin S.Yu. Pomoshch SShA slaborazvitym stranam. Garri Trumen $i$ «punkt-4» [U.S. Aid to Underdeveloped Countries. Harry Truman and the "Point Four"]. Saratov, Izd-vo SGU, 2017. 228 p.

4. Shenin S.Yu. Pomoshch SShA slaborazvitym stranam. Duayt Eyzenkhauer $i$ "otbrasyvaniye» kommunizma [U.S. Aid to Underdeveloped Countries. Dwight Eisenhower and the "Rollback" of Communism]. Saratov, Izd-vo SGU, 2018. 272 p.

5. Acheson D. What is Point Four? Address by the Secretary of State, January 25, 1952. Washington, D.C., GPO, 1952. 12 p. (Department of State Publication No. 4487).

6. Aid Funds Urgent, Truman Declares. The New York Times, 1959, April 5, p. 45.

7. Asia as a Region. The New York Times, 1955 , May 16, p. 22.

8. Bowles C. The Challenge of the Next Decade. The New York Times Magazine, 1957, April 21, pp. 189, 206-208.

9. Bowles C. The Crisis That Faces Us Will Not Wait. The New York Times Magazine, 1955, November 27, pp. 245, 266-270.

10. Cut in Interest for Aid is Balked. The New York Times, 1958, January 19, p. 59.

11. Eisenhower D. Report to Congress on the Mutual Security Program. Department of State Bulletin, 1954, vol. 30, no. 770, pp. 484-490.

12. Goldman M. Soviet Foreign Aid. New York, Washington, and London, Praeger, 1967. 265 p.

13. Haviland H. Foreign Aid and the Political Process: 1957. The American Political Science Review, 1958, vol. 52, no. 3, pp. 689-724.

14. Hoffman P. Blueprint for Foreign Aid. The New York Times Magazine, 1957, February 17, pp. 213, 237-239.

15. Hoffman P. World Investment, Not Foreign Aid. The New York Times Magazine, 1952, February 3, pp. 185, 204-206.

16. Kaufman B. The United States Response to the Soviet Economic Offensive of the 1950s. Diplomatic History, 1978, vol. 2, no. 2, pp. 153-165.

17. Kaufman B. Trade and Aid: Eisenhower's Foreign Economic Policy, 1953-1961. Baltimore, John Hopkins University Press, 1982. 296 p.

18. Lacy D. Foreign Aid: Is It Still Necessary? Harper's Magazine, 1957, February 16, pp. 71-80.

19. McGaffin W. Foreign Aid to Stay On. Chicago Daily News, 1957, March 6, p. 17.

20. More Foreign Aid Urged by Hoffman. Chicago Daily News, 1957, May 1, p. 22.

21. Reston J. A Gain for President. The New York Times, 1954, August 5, p. 2.

22. Rostow W. Eisenhower, Kennedy, and Foreign Aid. Austin, University of Texas Press, 1985. 342 p.

23. Schmidt D. Policy Appraisal Urged on Dulles. The New York Times, 1955, November 29, p. 1. 
С.Ю. Шенин. Эволюция американской программы помощи и фактор советского «экономического наступления»

24. Speech by Sen. Hubert H. Humphrey, February 12, 1957. Congressional Record. Proceedings and Debates of the $85^{\text {th }}$ Congress, $1^{\text {st }}$ Session. Washington, D.C., GPO, 1957, vol. 103, part 2, pp. 1421-2848.

25. Staley E. The Future of Underdeveloped Countries: Political Implications on Economic Development. New York, Harper, 1961. 483 p.

26. Thorp W. American Policy and the Soviet Economic Offensive. Foreign Affairs, 1957, vol. 35, no. 2, pp. 271-282.

27. U.S. Congress. House of Representatives. Mutual Security Act of 1958. Hearings Before the
Committee on Foreign Affairs on H.R.12181. $85^{\text {th }}$ Congress, $2^{\text {nd }}$ Session. Washington, D.C., GPO, $1958.992 \mathrm{p}$.

28. U.S. Congress. Senate. Foreign Assistance Activities of the Communist Bloc and Their Implications for the United States. $85^{\text {th }}$ Congress, $1^{\text {st }}$ Session. Washington, D.C., GPO, 1957. 134 p.

29. U.S. International Cooperation Administration. Office of Public Reports. Background for Mutual Security. Washington, GPO, 1955.26p.

30. Wehrwein A. Kennedy Visions Wide Negro Role. The New York Times, 1959, April 13, p. 56.

\section{Information About the Author}

Sergey Yu. Shenin, Doctor of Sciences (History), Professor, Department of International Relations and Russian Foreign Policy, Saratov State University, Astrakhanskaya St, 83, 410012 Saratov, Russian Federation, shenins@yahoo.com, https://orcid.org/0000-0002-4503-5923

\section{Информация об авторе}

Сергей Юрьевич Шенин, доктор исторических наук, профессор кафедры международных отношений и внешней политики России, Саратовский национальный исследовательский государственный университет им. Н.Г. Чернышевского, ул. Астраханская, 83, 410012 г. Саратов, Российская Федерация, shenins@yahoo.com, https://orcid.org/0000-0002-4503-5923 